\title{
PENGGUNAAN ELT WEBSITE UNTUK MENINGKATKAN KOMPETENSI GURU-GURU SMP DALAM KETRAMPILAN MENYIMAK
}

\author{
Hermariyanti Kusumadewi \\ Universitas Indraprasta PGRI \\ 081289493291 \\ hermariyanti@gmail.com
}

\begin{abstract}
ABSTRAK
Menyimak (listening) merupakan suatu kegiatan di mana kita tidak hanya dapat mengerti ujaran-ujaran lisan, tetapi kita juga dapat merespon ujaran tersebut. Tujuan dari penelitian ini adalah untuk mengetahui apakah penggunaan ELT Web dapat meningkatkan kompetensi guru-guru SMP dalam ketrampilan menyimak (listening skill) dan lebih lanjut dengan adanya tulisan ini dapat memberikan variasi untuk mengajarkan menyimak (listening) dengan memanfaatkan teknologi. Metode yang digunakan dari penelitian ini adalah metode kuantitatif. Sampel dalam penelitian ini adalah guru-guru SMP. Peneliti memberikan soal menyimak pre-test dalam bentuk pilihan ganda, dan soal menyimak post-test setelah latihan menggunakan ELT Website. Hasil dari penelitian ini menunjukkan adanya peningkatan ketrampilan menyimak yang ditunjukkan dengan peningkatan nilai post-test.
\end{abstract}

Kata Kunci: ELT website, ketrampilan menyimak

\section{ABSTRACT}

Listening is an activity in which we can not only understand oral speech, but we can also respond to that utterance. The purpose of this study is to find out whether the use of ELT Web can improve the competence of junior high school teachers in listening skill and further with this paper can provide variation to teach listening by using technology. The method used from this research is quantitative method. The sample in this research is junior high school teachers. The researcher gave the question of pre-test in multiple choice, and listening post-test after practice using ELT Website. The results of this study indicate an increase in listening skills as indicated by the increase in post-test values.

Key Words: ELT website, listening skills

\section{PENDAHULUAN}

\section{Latarbelakang}

Perkembangan telekomunikasi dan teknologi semakin pesat saat ini. Dengan pesatnya perkembangan teknologi ada baiknya diimbangi dengan meningkatnya kualitas sumber daya manusia. Beberapa tahun ini, saya memperhatikan fenomena yang terjadi di era digital. Sebut saja penggunaan smartphone yang selalu bertengger di genggaman setiap orang. Jika dilihat dari sisi positifnya, hal ini sangat bermanfaat karena internet bisa dikatakan sebagai jendela dunia, hal ini didukung oleh Dudeney dan Hocklin (2007:27) "The web is a source of content which can be used as a window on the wider world outside your class, and is - of course - a readily available collection of authentic material." Bagi kebanyakan orang yang 
menganggap segala sesuatu dapat diketahui melalui internet, belajar dan menimba ilmu melalui internet, internet bisa berarti segalanya. Namun, hal yang perlu diketahui adalah tidak semua yang ada di internet itu benar. Bahkan banyak sekali situs yang tidak dapat diakui kebenarannya. Maka dari itu tidak semua situs internet dapat dijadikan pendukung kegiatan pembelajaran maupun referensi dalam tulisan ilmiah.

Era digital juga banyak mempengaruhi dunia pendidikan. Dalam pembelajaran Bahasa, adanya teknologi computer, internet dan smartphone sangat membantu proses meningkatkan empat ketrampilan Bahasa. Guru dan tenaga pengajar lain terbantu dengan adanya internet. Dengan kemajuan teknologi saat ini, guru dengan mudah dapat mencari materi ajar, ataupun latihan-latihan soal bahkan dapat berinteraksi secara tidak langsung dengan murid-murid melalui media internet. Ada banyak sekali situs yang dapat mendukung kegiatan belajar mengajar.

Dalam pembelajaran Bahasa, dengan memanfaatkan banyaknya materi yang ada di internet dapat meningkatkan kualitas profesi. Dalam buku How to Teach English with Technology, Dudeney dan Hockly menyatakan "you can choose from authentic (written for internet surfers in general) sources or ELT-specific sites (made by, and for, teachers)."Ada dua tipe situs yang bisa dijadikan referensi, pertama authentic website yang merupakan website umum yang dapat mendukung semua kegiatan pembelajaran dalam mata pelaran apapun. Kedua, ELT website, dilihat dari namanya (English for Language Teaching) website ini menyajikan segala sesuatu yang dapat mendukung pembelajaran Bahasa Inggis. Ada banyak sekali ELT web yang dapat dimanfaatkan untuk mendukung pembelajaran Bahasa Inggris.

Sebagai contoh, dalam pembelajaran menyimak, satu dekade yang lalu masih menggunakan media tape dan kaset, lalu berkembang dengan menggunakan compact disc dan cd player. Saat ini, pembelajaran menyimak dapat didukung dengan media internet. Banyak situs yang dapat mendukung pembelajaran menyimak. Dengan adanya ELT web yang menyediakan materi dan latihan-latihan berupa audio dapat memudahkan guru untuk memanfaatkannya sebagai media pendukung pembelajaran.

Ketrampilan menyimak merupakan ketrampilan reseptif sama halnya dengan membaca. Menurut Richard Norquish dalam website grammar.about.com (https://www.thoughtco.com/english-grammar-4133049 menyatakan "Listening is the active process of receiving and responding to spoken (and sometimes unspoken) messages." Dari dari definisi tersebut menyimak dapat diartikan sebagai proses aktif menerima dan menanggapi pesan yang diucapkan (dan kadang-kadang tak terucapkan). Ketrampilan ini juga merupakan ketrampilan pertama yang harus dikuasai saat belajar Bahasa, sebagai ketrampilan dasar, menyimak mempunyai peran penting untuk mempengaruhi tiga ketrampilan Bahasa lainnya; berbicara, membaca, dan menulis.

Sebagai bahasa Asing, tentunya pemelajar bahasa menghadapi kesulitan dalam belajar bahasa Ingris. Seperti dikatakan sebelumnya, bahwa listening adalah ketrampilan dasar yang dapat mempengaruhi ketrampilan-ketrampilan berbahasa lainnya, maka ELL (English Language Learners) harus menguasi ketrampilan ini dengan baik. Namun, pada kenyataannya ada beberapa kendala yang dihadapi pemelajar bahasa asing dalam menyimak bahasa Ingris. Hal-hal yang paling banyak 
ditemui adalah pemelajar tidak terbiasa menyimak bahasa Inggris, adanya perbedaan aksen bahasa Inggris british dan American, kurangnya pengetahuan kosakata, dan malasnya latihan menyimak. Hal ini senada dengan yg diungkapkan Sumihatul Ummah dalam Jurnal Nuansa Vol. 9 No. 12012 "banyak faktor yang menyebabkan mahasiswa kesulitan belajar Listening Comprehension misalnya: materi terlalu cepat untuk didengarkan sehingga lupa dengan apa yang telah mereka dengar, tidak mengenal arti kata dalam bahasa inggris yang diucapkan atau didengarkan karena adanya keterbatasan English vocabulary yang mereka miliki, tidak konsentrasi terhadap materi yang didengarkan, tidak mengerti perintah yang dijelaskan secara verbal, malas dalam belajar atau tidak ada motivasi belajar, dan banyak pula faktor lainnya."

"Technology is useful to teach listening because each type of technology provides opportunities for students to explore their ranges of listening strategies. And it allows for more emphasis on certain aspects, such as cross-cultural, interactional, critical, and contextual dimensions of listening, to be developed. Technology also makes learning process of listening more entertaining." ( Source: Second Language Listening : Theory and Practice. John Flowerdew Page:182)

Mengacu pada permasalahan yang telah disampaikan di atas, fokus tulisan ini adalah penggunaan ELT Web dalam Pembelajaran Listening Comprehension, dan untuk meningkatkan ketrampilan menyimak bahasa Inggris.Dari latar belakang yang sudah dipaparkan di atas, tujuan dari penelitian ini adalah untuk mengetahui sejauh mana penggunaan ELT web dapat meningkatkan ketrampilan menyimak bahasa Inggris.

\section{PengertianMedia Pembelajaran}

Gerlach dan Ely dalam Suaib (2015) memandang media pembelajaran bukan hanya berupa alat dan bahan saja, akan tetapi hal-hal yang memungkinkan siswa dapat memperoleh pengetahuan. "A medium, conceived is any person, material or even that establish condition which enable the learner to acquire knowledge, skill, attitude." Secara umum media (pembelajaran) itu meliputi orang, bahan, peralatan, atau kegiatan yang memungkinkan siswa memperoleh pengetahuan, ketrampilan, dan sikap.

Senada dengan pendapat di atas, Rossi dan Breidle dalam Suaib (2015) mengatakan bahwa "media pembe-lajaran adalah seluruh alat dan bahan yang dapat dipakai untuk tujuan pendidikan seperti radio, televisi, buku, koran, majalah dan sebagainya." Alat-alat semacam radio dan televisi bila digunakan dan diprogram untuk pendidikan, maka merupakan media pembelajaran.

Lebih lanjut, Gagne dalam Suaib (2015) mengatakan bahwa "media pembelajaran adalah sebagai komponen yang ada dalam lingkungan siswa yang dapat merangsang pembelajaran." Sedangkan Miarso (2004), berpendapat bahwa "media pembelajaran adalah segala sesuatu yang digunakan untuk menyalurkan pesan serta dapat merangsang pikiran, perasaan, perhatian, dan kemauan si pelajar sehingga dapat mendorong terjadinya proses belajar". 
Hernawan dan Herry (2007: 6) menjelaskan ada tiga jenis media pembelajaran yang dapat dikembangkan dan digunakan dalam kegiatan pembelajaran oleh guru di sekolah, yaitu:

1) Media visual, media yang hanya dapat dilihat dengan menggunakan indra penglihatan terdiri atas media yang dapat diproyeksikan (projected visual) dan media yang tidak dapat diproyeksikan (non projected visual).

2) Media audio, media yang mengandung pesan dalam bentuk auditif yang dapat merangsang pikiran, perasaan, perhatian, dan kemauan para siswa untuk mempelajari bahan ajar dan jenisnya.

3) Media audio visual, merupakan kombinasi dari media audio dan media visual atau media pandang dengar."

berikut.

Hamalik (2008) mendeskripsikan fungsi media pembelajaran sebagai

1) Untuk mewujudkan situasi pembelajaran yang efektif.

2) Penggunaan media merupakan bagian internal dari sistem pembelajaran.

3) Penggunaan media dalam pembelajaran adalah untuk mempercepat proses pembelajaran dan membantu siswa dalam upaya memahami materi yang disajikan oleh guru dalam kelas.

4) Untuk mempertinggi mutu pendidikan.

Dari beberapa teori di atas, dapat disimpulkan bahwa media pembelajaran adalah suatu alat atau sarana yang digunakan dalam proses pembelajaran untuk menunjang minat, perhatian, dan kemampuan siswa dalam mempelajari suatu pelajaran. Media pembelajaran juga diklasifikasikan ke dalam beberapa kategori yaitu media pembelajaran audio, media pembelajaran visual, dan media pembelajaran audio visual.

Dari segi perkembangan teknologi, media pembelajaran dapat dikelompokkan menjadi dua kategori luas, yaitu pilihan media tradisional dan pilihan media teknologi mutakhir (Seels \& Glasgow dalam Arsyad, 2002:33). Lebih lanjut dijelaskan bahwa pilihan media tradisional dapat dibedakan menjadi (1) visual diam yang diproyeksikan, misal proyeksi opaque (tak tembus pandang), proyeksi overhead, slides, dan filmstrips, (2) visual yang tidak diproyeksikan, misal gambar, poster, foto, charts, grafik, diagram, pemaran, papan info, (3) penyajian multimedia, misal slide plus suara (tape), multi-image, (4) visual dinamis yang diproyeksikan, misal film, televisi, video, (5) cetak, misal buku teks, modul, teks terprogram, workbook, majalah ilmiah/berkala, lembaran lepas (hand-out), (6) permainan, misal teka-teki, simulasi, permainan papan, dan (7) realia, misal model, specimen (contoh), manipulatif (peta, boneka). Sedangkan pilihan media teknologi mutakhir dibedakan menjadi (1) media berbasis telekomunikasi, misal teleconference, kuliah jarak jauh, dan (2) media berbasis mikroprosesor, misal computer-assistted instruction, permainan komputer, sistem tutor intelejen, interaktif, hypermedia, dan compact (video) disc.

\section{Pengertian Media Internet $E L T$ Web}

Dudeney dan Hockly (2006: 27) "The web is a source of content which can be used as a window on the wider world outside your class, and is - of course - a readily available collection of authentic material." Lebih lanjut, Dudeney dan 
Hocklin menyatakan "Internet is a vast repository of information and resources, and it is perhaps exactly this range that makes it seem, at first, daunting and unapproachable to most teachers." Web adalah sumber konten yang dapat digunakan sebagai jendela di dunia yang lebih luas di luar kelas Anda, dan tentu saja - koleksi materi otentik yang tersedia." Lebih lanjut, Dudeney dan Hocklin menyatakan "Internet adalah gudang informasi dan sumber daya yang sangat luas, dan mungkin inilah rentang yang membuatnya tampak pada awalnya menakutkan dan tidak dapat didekati oleh kebanyakan guru.

Adapun dalam memilih website, kita harus memilih web yang baik. Berikut adalah kriteria website yang baik menurut Dudeney dan Hockly (2006:34)

1. Accuracy: who wrote the page? Is this person an expert in the subject matter? Check qualifications, experience. Is the page content reliable and factuality correct? Cross-reference with other similar websites and encyclopedias.

2. Currency: is the content up to date? Check factual information against other reliable sources. When was the page last update? Check for information at the bottom/top of the page.

3. Content: is the site interesting and stimulating? Considers the content from learners' point of view.

4. Functionality: does the site work well? Be sure to check all pages.

Akurasi: siapa yang menulis halaman? Apakah orang ini ahli dalam materi pelajaran? Periksa kualifikasi, pengalaman. Apakah konten halamannya bisa diandalkan dan faktualitasnya benar? Referensi silang dengan situs dan ensiklopedi serupa lainnya. Hal masih berlaku: apakah isinya up to date? Periksa informasi faktual terhadap sumber terpercaya lainnya. Kapan halaman terakhir diupdate? Periksa informasi di bagian bawah/atas halaman. Konten: apakah situs itu menarik dan merangsang? Mempertimbangkan isi dari sudut pandang peserta didik. Fungsionalitas: apakah situs bekerja dengan baik? Pastikan untuk memeriksa semua halaman.

\section{Pengertian Menyimak}

Menyimak mengarah ke pemahaman fakta dan ide-ide. Akan tetapi,menyimak membutuhkan perhatian, atau menempel tugas di tangan terlepas dari gangguan. Hal ini membutuhkan konsentrasi, yang merupakan fokus dari pikiran Anda pada satu masalah tertentu. Seseorang yang menggabungkan mendengarkan dengan konsentrasi secara aktif mendengarkan. Aktif mendengarkan adalah metode menanggapi lain yang mendorong komunikasi.

Menurut Dawson dkk. (dalam Tarigan (2008 : 2) yaitu meningkatkan keterampilan menyimak berarti membantu meningkatkan kualitas berbicara seseorang. Kemudian bunyi atau suara merupakan suatu faktor penting dalam peningkatan cara pemakaian kata - kata peserta didik. Oleh karena itu, peserta didik akan tertolong kalau mereka mendengarkan atau menyimak ujaran - ujaran yang baik dari para guru, rekaman-rekaman yang bermutu, dan cerita - cerita yang bernilai tinggi.

Abidin (2012:93) menyatakan bahwa menyimak dapat diartikan sebagai kegiatan aktif yang dilakukan secara sungguh-sungguh untuk memahami pesan yang terkandung dalam bahan simakan yang diperdengarkan secara lisan. 
Dalam keterampilan menyimak dibutuhkan batasan untuk menyatakan bahwa seseorang tersebut terampil. Seseorang dapat dikatakan terampil menyimak apabila ia dapat menyerap-menangkap gagasan-pikiran yang disimaknya atau yang disampaikan orang lain kepadanya secara lisan, dengan tepat, benar, akurat, dan lengkap (Nurjamal, dkk; 2011:3).

Keterampilan menyimak juga merupakan dasar atau faktor penting bagi suksesnya seseorang dalam belajar membaca secara efektif. Menyimak turut membantu peserta didik untuk menangkap ide utama yang diajukan oleh pembicara.

Berdasarkan uraian di atas, dapat ditegaskan bahwa menyimak merupakan suatu proses yang mencakup kegiatan mendengarkan bunyi bahasa, mengidentifikasi, menafsirkan, menilai, dan mereaksi atas makna yang terkandung di dalam wacana lisan. Menyimak dalam penelitian ini adalah mendengarkan dengan penuh perhatian, menginterpretasikan, dan mereaksi atas makna yang terkandung di dalamnya.

\section{Jenis Menyimak}

Menyimak ada berbagai jenis, namun beberapa jenis tersebut dibedakan berdasarkan kriteria tertentu.Menyimak, dibagi menjadi dua ragam, yakni menyimak intensif dan menyimak ekstensif.

a) Menyimak Intensif : Menyimak intensif Menyimak intensif adalah kegiatan menyimak dengan penuh perhatian, ketentuan dan ketelitian, sehingga penyimak memahami secara mendalam

b) Menyimak ekstensif : Menyimak ekstensif adalah proses menyimak yang dilakukan dalam kehidupan sehari-hari, seperti: menyimak radio, televisi, percakapan orang di pasar, pengumuman, dan sebagainya.

Adapun menyimak dibagi menjadi empat bagian yaitu (1) menyimak sosial (social listening) atau menyimak konversasional (conversational listening) atau pun menyimak sopan (corteous listening) biasanya berlangsung dalam situasi - situasi sosial tempat orang mengobrol atau bercengkerama mengenai hal - hal yang menarik perhatian semua orang yang hadir. (2) Menyimak sekunder (secondary listening) adalah sejenis kegiatan menyimak secara kebetulan (casual listening) dan secara ekstensif (extensive listening). Menyimak estetik (aesthetic listening) ataupun yang disebut menyimak apresiasif (appreciational listening) adalah fase terakhir dan kegitan termasuk ke dalam menyimak secara kebetulan dan menyimak secara ekstensif. (4) Menyimak pasif adalah penyerapan suatu ujaran tanpa upaya sadar yang biasanya menandai upaya-upaya kita pada saat belajar dengan kurang teliti, tergesa - gesa, menghafal luar kepala, berlatih santai, serta menguasai suatu bahasa. (Dawson et al, dalam Tarigan 2014:41).

\section{METODE PENELITIAN}

Sampel dari penelitian ini adalah guru-guru SMP di Bekasi (SMPN 9 Kota Bekasi dan SMPN 34 Kota Bekasi) yang berjumlah 20 Orang. Peneliti menggunakan pre-test dan posttest sebagai instrumen pengambilan data yang selanjutnya akan dihitung perbandingan nilai ketrampilan menyimak dari sebelum menggunakan media ELT dan setelah mengunakan media ELT.Dalam penelitian ini peserta didik akan diberikan tes menggunakan 20 soal pilihan ganda dengan pilihan: A, B, C, dan D. Pre-test diberikan sekali sebelum diberikan perlakuan (treatment) pembelajaran dengan media ELT Website. Post-test di berikan sekali setelah diberikan perlakuan 
pembelajaran dengan media ELT Website.Perhitungan dilakukan dengan membandingkan nilai pre-test dan post-test dengan menggunakan metode statistik sederhana.

\section{HASIL DAN PEMBAHASAN}

Dalam menganalisis data, peneliti mendapatkan bahwa hasil menyimak bahasa Inggris guru-guru SMP di Bekasi memiliki kemampuan yang cukup dalam menyimak bahasa Inggris. Terlihat dari hasil kalkulasi analisis data, bahwa pemerolehan menyimak bahasa Inggris pada tabel sebagai berikut:

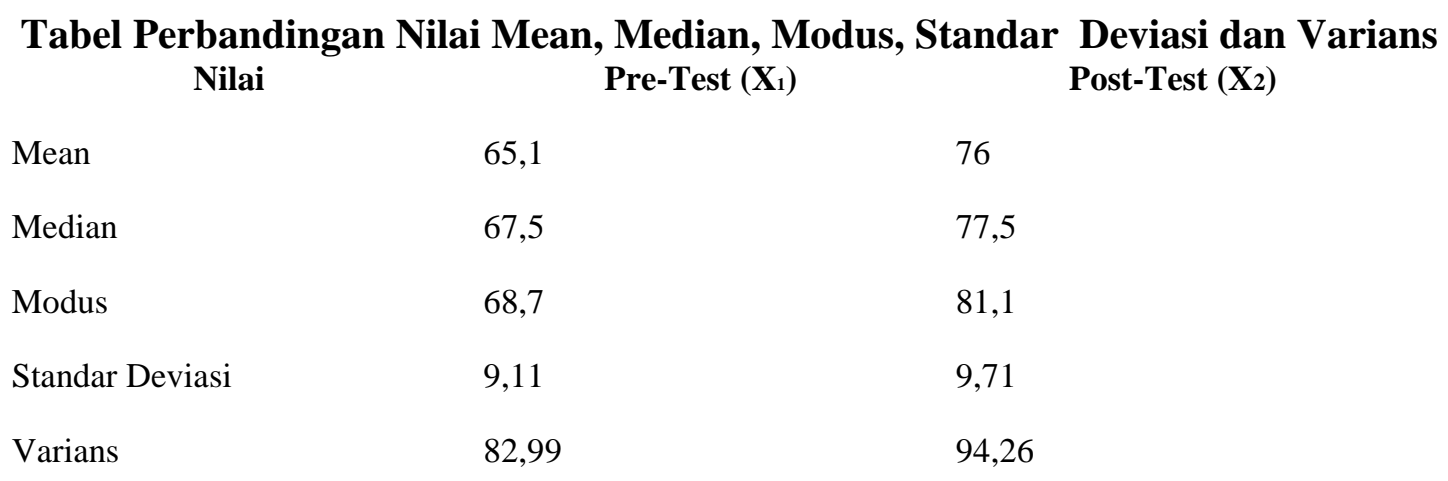

Tabel diatas menunjukan ringkasan statistik nilai mean, median, modus, standar deviasi, dan varians hasil dari pre-test dan post-test terhadap kemampuan menyimak bahasa Inggris. Pada uji persyaratan data, hasil hitung $t$-test menunjukan bahwa nilai $t_{\text {hitung }}$ sebesar 3,735 . Dengan menunjuk pada distribusi $t_{\text {tabel }}$ ini bisa dilihat bahwa degree of freedom $(20-2=18)$ yaitu nilai $t_{\text {tabel }}$ sebesar 2,025 pada tingkat $\alpha=0,05$. Maka nilai $t_{\text {hitung }}>t_{\text {tabel }}$, sehingga Ho ditolak yang berarti signifikan dan hipotesis $\mathrm{H}_{1}$ diterima. Hal ini dapat disimpulkan bahwa ada peningkatan yang signifikan dari penggunaan media ELT Website terhadap keterampilan menyimak guru-guru SMP di Bekasi.

Untuk dapat memahami konsep-konsep pembelajaran bahasa inggris melalui media ELT Web,guru-guru mengikuti kegiatan penggunaan media ELT Web untuk meningkatkan kompetensi dalam ketrampilan menyimak (listening skills) dengan tertib dan sangat antusias dengan topik tentangpeningkatan kompetensi guru melalui media ELT Web terhadap ketrampilan menyimak (listening skills). Dengan memanfaatkan media internet, ELT Webdapat meningkatkan keterampilan menyimak guru-guru. Mengacu pada adanya peningkatan nilai yang diperoleh guru-guru setelah latihan dengan menggunakan media ELT website, dapat disimpulkan bahwa dengan banyak latihan dapat meningkatkan keterampilan menyimak. Keterampilan menyimak, sebagai keterampilan reseptif, memengaruhi keterampilan bahasa lainnya. Olehkarena itu, penting untuk melatih keterampilan menyimak. 


\section{PENUTUP}

Hasil pengamatan berdasarkan yang dilakukan pada awal kegiatan, secara umummengindikasikan bahwa pembelajaran bahasa Inggris di Sekolah Menengah Pertama (SMP) berfokus pada pengenalan kata, pelafalan dan berbicara, membaca, tatabahasa, dan menulis teks sederhana. Teknik dan media yang digunakan dapat disesuaikan dengan kondisi lingkungan sekolah. Sebagian besar guru belum terbiasa dengan bahasa Inggris, dan tidak terbiasa baik menyimak kata maupun percakapan bahasa Inggris. Oleh karena itu, bahasa Inggris hanya disisipkan percakapan sederhana dan pengenalan kata. Beberapa peserta mengeluhkan pengucapan bahasa Inggris yang sulit dilafalkan, dan perlu latihan terlebih dahulu sebelum mengajarkan kepada siswa.Dengan adanya ELT Website ini, guru dapat berlatih menyimak dan melafalkan kata-kata bahasa Inggris dengan benar sebelum mengajarkan kepada siswa.

Dari hasil evaluasi terhadap peningkatan kompetensi guru melalui media ELT Web terhadap ketrampilan menyimak (listening skills), yang peneliti lakukan di akhir kegitan terlihat bahwa para guru sudah mulai paham dan bisa memanfaatkan internet untukmeningkatkan ketrampilan berbahasa Inggris dengan media ELT Web terhadap ketrampilan menyimak (listening skills) walaupun dari segi teknis mereka belum terbiasa dengan pemanfaatan teknologi untuk meningkatkan kompetensi guru. 


\section{DAFTAR PUSTAKA}

Dudeney, Gavin and Nicky Hokcly. 2007. How to Teach English with Technology. England: Longman.

Flowerdew, John. 2005.Second Language Listening: Theory and Practice. Cambridge: Cambridge University Press.

Hamalik, O. 2008. Kurikulum dan Pembelajaran. Jakarta : PT. Bumi Aksara.

Hernawan, Asep, Herry dkk. 2007. Media Pembelajaran Sekolah Dasar edisi kesatu. Bandung: UPI PRESS.

Tarigan, Henry Guntur. 2014. Menyimak: Sebagai Suatu Keterampilan Berbahasa. Bandung: Angkasa Bandung.

Suseno, Imam, dkk. 2015. Pengantar Statistika Untuk Penelitian Pendidikan. Jakarta: Unindra Press.

https://www.thoughtco.com/english-grammar-4133049 (diakses pada tanggal 7Juli 2017)

https://ejournal.stainpamekasan.ac.id/index.php/nuansa/article/view/7 (diakses pada tanggal 5 Juli 2017)

http://eprints.unm.ac.id/2093/Suaib, Suaib (2015) Komparasi Peningkatan Hasil Belajar Tentang Garis dan Sudut dalam Penerapan Model Pembelajaran Kooperatif Tipe Teams Games Tournament dan Tipe Rotating Trio Exchange Siswa Kelas VII SMP Negeri 3 Duapitue. S1 thesis, Universitas Negeri Makassar (diakses pada tanggal 5 Juli 2017) 